\title{
Last instar larva of Trypoxylon (Trypoxylon) maidli Richards (Hymenoptera, Crabronidae), with biological notes on one nest
}

\author{
Sandor Christiano Buys
}

Laboratório de Entomologia, Departamento de Zoologia, Universidade Federal do Rio de Janeiro. Caixa Postal 68044, 21944-970 Rio de Janeiro, Brasil. E-mail: sbuys@biologia.ufrj.br

\begin{abstract}
The last larval instar and the cocoon of Trypoxylon (Trypoxylon) maidli Richards, 1934 are described. This larva is apparently indistinguishable from that of $T$. clavicerum exiguum Tsuneki, 1956. They can be distinguished from larvae of other species in the subgenus by the following features: integument of body smooth, sensilla on both sensorial area and labrum, and distinct parietal bands. Notes on nesting site and preys from one nest are presented. Eurycoma insigne (Millidge, 1991) (Linyphiidae) and Argiope argentata (Fabricius, 1775) (Araneidae) are reported as preys.
\end{abstract}

KEY WORDS. Biology, immature, prey, systematic, wasp.

Trypoxylon Latreille, 1796 is a large and widespread genus of spider-hunting wasps, which nests in pre-existent cavities or constructs mud nests. This genus is usually split into two subgenera, Trypoxylon and Trypargylum Richards, 1934, based on morphological and behavioural features (RichARDs 1934, Krombein 1967, Bohart \& MenKe 1976). There are descriptions of the last larval instar of nine species of Trypoxylon (Trypoxylon): T. elongatum Smith, 1856 (Williams 1919, Evans 1957), T. figulum (Linnaeus, 1758); (SoIKA 1934), T. aldrichi Sandhouse, 1940; T. frigidum Smith, 1856; T. johnsoni Fox, 1891, (as T. adelphiae Sandhouse, 1940) (Evans 1957); T. bicolor Smith, 1856 (Yоsнгмото 1964); T. clavicerum exiguum Tsuneki, 1956; T. malaise Gussakovskji, 1933 (IIDA 1969); and T. attenuatum Smith, 1851 (Asís et al. 1994). The last instar larva of the mud-dauber $T$. (Trypoxylon) maidli Richards, 1934 is herein described and notes on its nest are presented.

\section{MATERIAL AND METHODS}

One multicelular nest bearing larvae and preys was collected in the Reserva Biológica de Poço das Antas, Rio de Janeiro State, southern Brazil. The larvae were killed and preserved in alcohol (90\%). The head and the entire body of two last instar larvae were separately heated in $\mathrm{KOH}(10 \%)$ for about 10 minutes to eliminate the soft tissues. The description was based on two last instar larvae and one cocoon, but the morphometric features were taken from a single larva. Adult specimens of the wasp have been deposited in the Museu de Zoologia da Universidade de São Paulo, São Paulo State, Brazil (MZUSP); the preys have been deposited in the Museu Nacional / Universidade Federal do Rio de Janeiro, Rio de Janeiro State, Brazil (MNRJ).

\section{RESULTS}

Trypoxylon (Trypoxylon) maidli Richards, 1934

\section{Last instar larva (Figs 1-5)}

Body. White. Cylindrical. Pleural lobes rounded on thorax and abdomen. Thoracic segments dorsally very prominent. Anal segment somewhat truncate. Integument smooth; transverse rows of setae on thoracic segments; prothorax and mesothorax with about ten setae each, 23-40 $\mu \mathrm{m}$ long; metathorax with four setae, 23-30 $\mu \mathrm{m}$ long; setae sparsely distributed on abdominal segments with no distinct pattern of distribution. Spiracles unpigmented, inconspicuous, about $45 \mu \mathrm{m}$ in diameter.

Head. $750 \mu \mathrm{m}$ in width and about $800 \mu \mathrm{m}$ in height. Coronal suture indistinct. Top and sides of the head weakly roughened. Parietal bands lightly pigmented. Antennal orbits subcircular, unpigmented, very inconspicuous, about $40 \mu \mathrm{m}$ in diameter, with three small sensilla. Genal areas with three setae, about $50 \mu \mathrm{m}$ long. Frontal portion with seven setae, up to $60 \mu \mathrm{m}$ long, sparsely distributed. Anterior tentorial arms and hypostoma unpigmented; pleurostoma pigmented only in the two points of articulation with the mandibles, with about 7-10 punctures roughly aligned. Epistomal suture distinct. Clypeus with a few sparse punctures and four setae, about 40$45 \mu \mathrm{m}$ long.

Mouthparts. Labrum approximately quadrangular; $258 \mu \mathrm{m}$ in width and $128 \mu \mathrm{m}$ in height; with nine setae, 23$30 \mu \mathrm{m}$ long; lateral margins with two unpigmented, conical, sencilla; apical margin with about ten small pigmented, papilliform sensillae which extend to the epipharynx. Epipharynx 


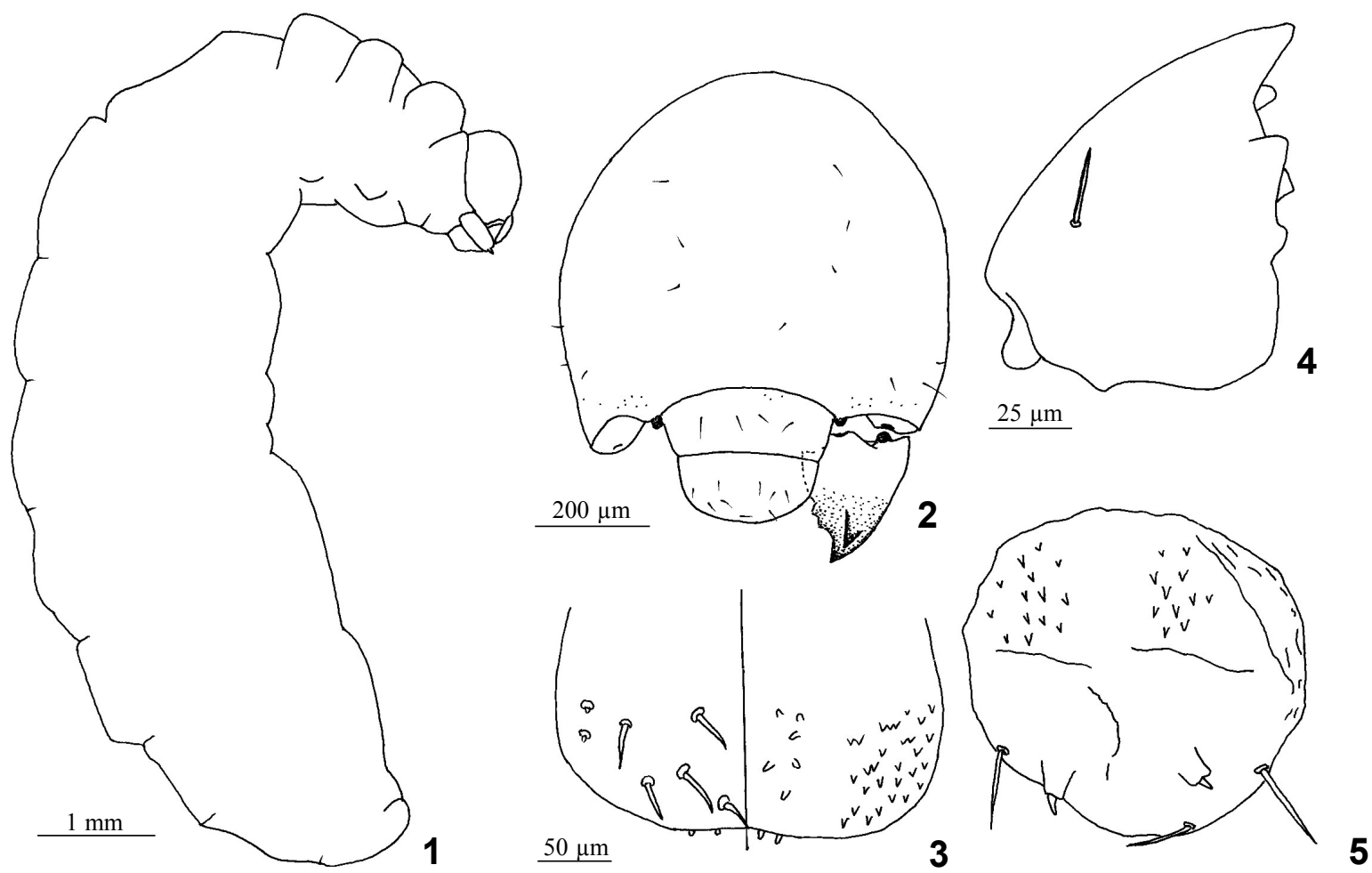

Figures 1-5. Trypoxylon maidli, last instar larva. (1) Body, lateral view; (2) head with the mouthparts partially dissected, frontal view, showing distribution of setae; (3) labrum and epipharynx, frontal view; (4) dissected mandible, frontal view; (5) dissected labium, frontal view.

with sparse spines, all of them turned to the apex, concentrated on lateral portions; sensorial area with six pigmented papilliform sensillae. Mandibles pigmented from the middle to the apex, on the mandibular internal articulation and on the apical portion of the external mandibular articulation; with five teeth; one seta, $25 \mu \mathrm{m}$ long, laterally on the base. Maxillae with six lateral setae, up to $25 \mu \mathrm{m}$ long; maxillary palpi conic, $50 \mu \mathrm{m}$ long, unpigmented; galeae with about $15 \mu \mathrm{m}$ long, unpigmented; lacinial area with sparse spines, up to $5 \mu \mathrm{m}$ long, and an angular lobe. Labium rounded; $170 \mu \mathrm{m}$ wide; with two conspicuous setae on lateral portions; six setae on ventral face, up to $25 \mu \mathrm{m}$ long; labial palpi conic, about $25 \mu \mathrm{m}$ long; unpigmented; oral portion with two sparsely spinulose areas.

\section{Cocoon}

Cylindrical; wall formed by one layer of silk; brownish in colour, opaque; texture malleable. Meconium in the posterior extremity; dark; cylindrical; isolated from the rest of cocoon by a wall of silk.

\section{Nest site and preys}

The collected nest was firmly attached to a tree trunk in a shaded place, approximately $1.60 \mathrm{~m}$ from the ground. This nest was constituted by several cells, but it was not possible to determine the number of cells because the nest broke in the moment of the collect. The nest bore 50 specimens of Eurycoma insigne (Millidge, 1991) (Linyphiidae) (nine immature males, two adult males, two immature females, and 31 adult females), and two immature specimens of Argiope argentata (Fabricius, 1775) (Araneidae).

\section{DISCUSSION}

The two examined specimens did not have visible spinnerets, but it seems likely that this structure was lost during the treatment of the material. The known larvae of Trypoxylon and those of the related genus Pison Jurine, 1808 have developed spinnerets (SoIKA 1934, Evans 1957, Yоsнimoto 1964, IIDA 1969, Asís et al. 1994). It was not observed significant morphological variation among the examined specimens. The only remarkable feature is the cephalic rugosity present in only one specimen, although weakly developed.

The larvae of $T$. maidli and T. clavicerum exiguum are unique among the described larvae of species of Trypoxylon (Trypoxylon) in bearing sensilla on both sensorial area and labrum. T. figulum has six somewhat conical sensilla on the apical margin of the epipharynx (SorkA 1934). T. attenuatum have small sensilla on lateral margins of the labrum similar to that of T. maidli (Asís et al. 1994), however, the number of sensilla is different. T. maidli, T. clavicerum exiguum, T. malaise (IIDA 1969) and T. bicolor (Үознімото 1964) are similar in having distinguishable parietal bands. T. aldrichi, T. frigidum, and T. adelphiae

Revista Brasileira de Zoologia 20 (3): 447-449, setembro 2003 
are quite similar, but they could be distinguished by features in the labrum and epipharynx (Evans 1957). T. malaise (IIDA 1969) and T. attenuatum (Asís et al. 1994) bear the body covered with minute spines. This feature distinguishes these two species from the aforementioned ones.

VASEY-FITZGERALD (1936) described the cocoon of T. maidli as white rather than brownish and presented notes on the biology of this species from Trinidad, which agree in general lines with those done in Brazil.

\section{ACKNOWLEDGEMENTS}

I thank Sérvio T. Amarante for identifying the wasp, Renner Baptista for identifying the spiders, and José Ricardo Ribeiro, Alexandre Feitosa, and Celso Oliveira Azevedo for the reading of the manuscript.

\section{REFERENCES}

Asís, J.D.; J. Tormos \& S.F. Gayubo. 1994. Biological observations on Trypoxylon attenuatum and description of its mature larvae and its natural enemy Trichysis cyanea (Hymenoptera: Sphecidae, Chrysididae). Journal of the Kansas Entomological Society, Manhattan, 67 (2): 199-207.

BOHART, R.M. \& A.S. MENKE. 1976. Sphecidae wasps of the world - a generic revision. Berkeley, University of California Press, $665 \mathrm{p}$.
Evans, H.E. 1957. Studies on the larvae of digger wasps (Hymenoptera, Sphecidae) Part III: Philanthinae, Trypoxylinae, and Crabroninae. Transactions of the American Entomological Society, Philadelphia, 83: 79-117+IX-XX.

IIDA, T. 1969. Contributions to the knowledge on the sphecid larvae in Japan (Hymenoptera). Part I. Kontyû, Tokyo, 37 (3): 272-279.

Krombein, K.V. 1967. Superfamily Sphecoidea, p. 386-421. In: K.V. Krombein \& B.D. Burks. (Eds). Hymenoptera of America north of Mexico, synoptic catalog. Washington, D.C., U.S. Department of Agriculture, Agriculture Monograph 2, supplement 2, 584p.

Richards, O.W. 1934. The American species of the genus Trypoxylon. Transactions of the Royal Entomological Society of London, London, 82: 173-360.

SoIKA, A.G. 1934. Etudes sur les larves des hyménoptères. Annales de la Societe Entomologique de France, Paris, 103: 337-344.

Vasey-Fitzgerald, D. 1936. Nesting habits of Trypoxylon from Trinidad. Proceedings of the Royal Entomological Society of London, series A, London, 11: 111-114.

Williams, F.X. 1919. Philippine wasp studies. Bulletin of the Experimental Station of the Hawaiian Sugar Planters' Association, Entomological series, Honolulu, 14: 1-186.

Yоsнімото, C.M. 1964. Nesting activity and larval description of Trypoxylon (Trypoxylon) bicolor Smith (Hymenoptera: Sphecidae) in Hawaii. Pacific Insects, Honolulu, 6 (3): 517-521.

Received in 06.III.2003; accepted in 14.VIII.2003.

Revista Brasileira de Zoologia 20 (3): 447-449, setembro 2003 